\title{
密集市街地におけるスーパー台風に伴う 高潮氾濫時の大規模地下空間浸水について UNDERGORUND INUNDATION BY STORM SURGE CAUSED BY SUPER TYPHOON
}

\author{
演口舜 1 ・石垣泰輔 2 ・島田広昭 3 ・尾﨑平 3 ・ 戸田圭一 4 \\ Shun HAMAGUCHI, Taisuke ISHIGAKI, Hiroaki SHIMADA, Taira OZAKI and Keiichi TODA \\ 1学生会員 関西大学大学院 理工学研究科（干564-8680 吹田市山手町3-3-35） \\ 2正会員 博(工) 関西大学教授 環境都市工学部 都市システム工学科（テ564-8680 吹田市山手町3-3-35） \\ 3正会員 博(工) 関西大学准教授 環境都市工学部 都市システム工学科（テ564-8680 吹田市山手町3-3-35） \\ 4 正会員 Ph.D. 京都大学大学院教授 工学研究科社会基盤工学専攻（广615-8540 京都市西京区京都大学桂）
}

\begin{abstract}
Some parts of Japanese mega cities such as Tokyo, Nagoya and Osaka are below sea level and these areas are prone to floods. These three areas are in coastal zone and over 1000 people were sacrificed by storm surge in the past time. Inundation of underground spaces by pluvial and tsunami flood in the center of Osaka have been investigated in our previous works. Underground inundation by storm surge caused by super typhoon is discussed in this paper. The results show that 50 percent of total overflow discharge intrudes into underground spaces. Almost all amount of intruding discharge into underground mall fall down to the subway stations connected to the mall. The damage is different from the results caused by pluvial and tsunami floods. This means that administrators of underground space have to make different countermeasures for each disaster.
\end{abstract}

Key Words : storm surge flooding, super typhoon, underground inundation, urban area

\section{1. はじめに}

近年，地球規模の温暖化の影響により集中豪雨や強い 熱帯低気圧，台風が増加している．都市部では下水道の 流下能力を上回る集中豪雨により, 内水汇濫が発生する 事例がみられる．また，台風接近に伴う高潮による被害 も確認されている. 都市機能が集積されている地区や住 宅密集地区において水災害が発生した場合，浸水による 直接的な被害だけでなく，交通機能障害や営業停止等の 間接被害が生じ，都市としての機能停止が危ぶまれる.

過去に日本の三大湾で起こった室戸台風(1934），伊 勢湾台風(1959), 関東大水害(1917)では多くの死者や都 市施設損害が発生した。当時は堤防などの防災設備が十 分ではなく，人々の高潮に対する知識や経験も不足して いたと思われる．近年では都市化の発達に伴い，地下空 間利用が多く見受けられることから，市街地に過去の災 害と同程度，もしくはそれ以上の高潮が襲来すると過去 にはなかった危険性や被害が発生することが予想される。 2012年にアメリカを襲ったハリケーンサンディは高潮に
よって地下空間浸水が起こり都市機能に被害を与えた. また，スーパー台風と呼ばれる，今まで以上の勢力を もった台風の発生が懸念されており，2013年フィリピン を襲った台風30号は6mを越える高潮が発生し, 台風の 勢力の強大化が明らかとなった. IPCC第5次報告書1)で も強い台風の発生が懸念されている。これまでに著者ら は, 研究対象地域とした日本を代表する大規模地下空間 を有する大阪市北区梅田周辺に着目し，内水汇濫，外水 氾濫，津波汇濫での地上の氾濫解析や地下空間浸水につ いて検討している. 図-1に研究対象地を示寸. 内水汇濫 では森兼ら2゙が行った平成20年8月末豪雨の岡崎市の観測 降雨を用いた研究や尾㠃ら33゙行った平成23年8月末の集 中豪雨の再現解析で対象地域での被害やモデルの精度を 証明した。 また, 浅野ら4)の研究では内閣府の南海トラ フ巨大地震の被害想定をもとに対象地域における津波氾 濫解析を行った。対象地域には海抜ゼロメートル地帯が 広がっており水害に対して脆弱であると考えられる。 そ こで，本研究ではこれまで検討されていなかった高潮氾 濫による地下空間浸水についての検討を行った，そして， 既往研究4)で行った対象地域における内水災害時と津波 
災害と高潮災害時の大規模地下空間に及ぼす浸水被害の 違いを検討することが目的である，水災害ごとに異なる 汇濫特性を把握し，具体的な安全避難方法や防災・減災 対策の方針を定めるために，水災害ごとの浸水特性につ いて検討した. 本研究では大阪湾高潮対策危機管理行動 計画ガイドライン ${ }^{5}$ を参考に，それらと同程度の高潮氾 濫計算を行い，計算モデルの計算精度を検証した。 そし て, 対象地域内のポンプ稼働時の減災効果についても検 討した。 これらの汇濫計算結果を用いて，大規模地下空 間における浸水特性について検討した。 さらに，既往研 究で比較されていた内水汇濫特性と津波汇濫特性の比較 に本研究による高潮汇濫特性を加え，大規模地下空間に 及ぼす浸水特性について比較・検討を行った，また，本 研究に関連する既往研究として, 東京東部低平地を対象 にした関根ら6の研究や名古屋市を対象とした武田ら7 の研究あげられる．いずれも三大湾である東京湾，伊勢 湾付近を対象としており, 対象地域は地盤高の低い土地 である.

本研究の特徴は, 既往研究2),3)で用いた計算モデルで 高潮汇濫解析を行い，対象地域における浸水状況を把握 寸ると共に，高潮汇濫流が大規模地下空間のいら，どの 地点で, ぞのように汇濫水が拡がるかを把握するために 考察を行い，大規模地下空間からの安全避難について検 討したことである.

対象地域は, 面積が1215haであり, 複数の河川に囲ま れている. 大阪市北区(梅田周辺)は，昼夜問わず老若男 女が集まり，百貨店・オフィスビル・ショッピングモー ル・ホテルなどが立ち並んでいる. 主要道路の地下には 地下街もある. これらの地下街は, 公的な地下街出入口 だけでも129箇所あり，隣接ビルや地下ショッピング街 などと結合し，日本最大級の地下街を形成している．交 通機関は, JR・私鉄・市営地下鉄の地上駅が2駅・地下 駅が5駅あり，交通の要衝といえる．また，交通量の多 い幹線道路が集中している。 さらに, 対象地域内には梅 田以外に地下駅が11駅存在しており, ゼロメートル地帯 や地盤の高いところに存在し様々な条件が存在する. 図 -2に対象地域内の終末処理場とポンプ場の位置を示す.

この処理区内は，終末処理場が1籄所，中継ポンプ場が3 箇所存在する. それらは対象地域内の雨水排除と污水処 理を担っており，その処理能力は，雨水に対しては $60 \mathrm{~mm} / \mathrm{hr}$ ，污水処理は $326000 \mathrm{~m}^{3} / \mathrm{day}$ である.

\section{2. 密集市街地の高潮汇濫}

\section{(1) 検討方法及び検討条件}

本研究では，下水道ネットワークと地上の氾濫水を同 時に計算できるInfoWorks CS(以下，IWCS)を用いた2)，3). IWCSは，有効降雨モデル，地表面流出モデル，管内水 理モデル，地表面氾濫計算モデルから構成されている.

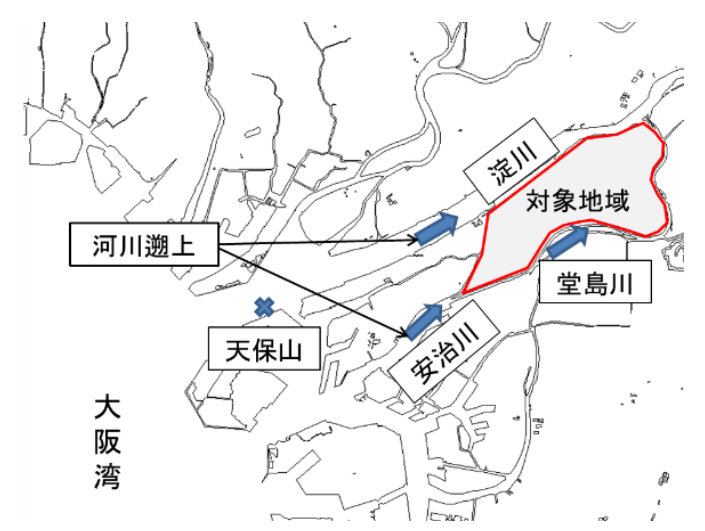

図-1 対象地域

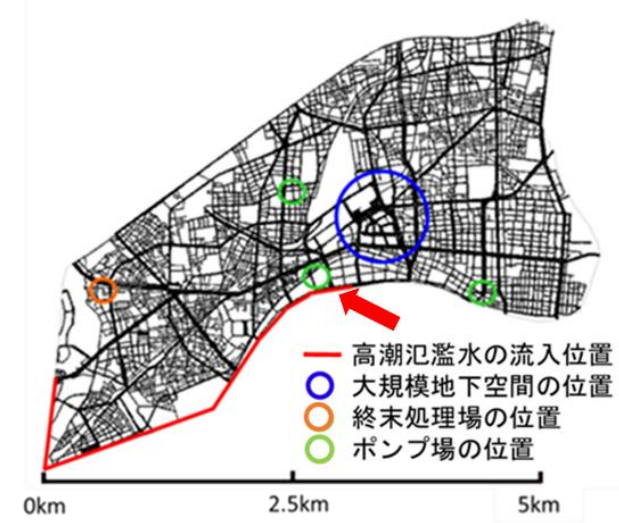

図-2＼cjkstart終末処理場とポンプ場の位置

地表面流出量は管内水理モデルのインプットデータとな り, 管渠内水理は, サン・ブナン式(圧力時はプライス マンのスロットモデル)により計算される。管渠につい ては，大阪市が公表している管経 $\phi 200 \mathrm{~mm}$ 以上の管渠 ネットワークを用いて計算を行った。 また，対象地域内 に存在する下水処理場及びポンプ場もモデル内に考慮し た．地盤高データは，航空レーザー測量による地盤高 データではなく, マンホールの地盤高データを用いた.

また，GISを活用し，1/2500の基盤地図をベースに道路 部と住区（街区）に分けた後に，道路上の中央分離帯や 擁壁等もモデル内に組み込んだ。地表面汇濫計算は, 非 構造格子による2次元不定流解析(浅水流方程式)である. マンホールからの格子への溢水量および格子からマン ホールへの流入量は，堰の公式を用いており，地表面氾 濫計算と管内水理解析は連動している. また, 地下街出 入口は，モデル内に現地調査に基づく道路面からの高さ， 出入口幅を堰で表現した. したがって, 地下街出入口付 近の道路における浸水深が堰高を超えると地下街へ流入 する. 本研究では梅田周辺部の公的な出入口129箇所を 対象とした. 接続ビル等については民間が管理するもの であり，それぞれが水防対策をすると想定し，考慮外と した. 次に, 高潮汇濫計算を行うために, 流入位置から 氾濫水が流入するようにモデル上に流入ラインを設けた。 流入ラインについては段落ち式で計算を行い，潮位高が 堤防を越流している時間のみ流入しているという条件で 
流入している. 本研究では河川をモデル内に考慮してい ないため流入ラインに接しているメッシュ上に同じ単位 幅流量の水が流れ込むものとしている. 河川を遡上して きた高潮汇濫水の流入位置を図-2に示寸，流入位置につ いては，大阪湾高潮対策危機管理行動計画ガイドライン (以下，ガイドライン)の解析結果の氾濫域(越流が発生 したと考えられる位置) と対象地域内の河川について現 地調查を行い，堤防の高さが低い地点から堤防の天端高 と橋梁の橋桁の高さが一致する場所(図-2赤矢印)までの 区間で流入すると想定した。 また，大阪湾から河道幅が 狭、安治川，堂島川(図-1)から高潮が河川遡上し，汇濫 水が図の赤線部から流入すると想定した. 高潮氾濫解析 はガイドラインのシナリオIIIの潮位データを使用した. ガイドラインにおける浸水シナリオは3つあり, ワース トケースであるシナリオIIIをを本研究では使用した。 シナ リオIIIの条件はスーパー室戸台風(900hPa)，基準潮位 T.P.+1.1m，堤防や水門等に破堤や機能不全が発生とい うものである. 図-3にガイドラインの解析結果の天保山 での潮位変動を示寸。これは天保山(図-1)における潮位 データであるので，このままのデータでは氾濫量が過大 なものになってしまう. そのため, ガイドラインにおけ るシナリオIIIIのヒーーク時の解析結果とIWCSにおける検 証解析の結果の比較を行い，流入条件を設定した。ここ では，ガイドラインと条件を同じにするため，モデル内 全体をメッシュで切り, 汇濫解析を行った. ガイドライ ンでは破堤を考慮していたが，本研究では破堤は考慮せ ず汇濫量を同等にし，結果を比較することで使用する データの妥当性を検証した．図-4にガイドラインの結果 と, IWCSでの検証の比較を示す. 越流水深を変化させ て氾濫計算を行い氾濫流域および浸水深がガイドライン の結果と一致するような汇濫量を決めて流入開始潮位を 設定した. 決定した越流水深は図-3の赤線部より上段で ある. 図-3中の赤線はT.P.+4.45mのラインでありこれを 超えている時間を流入時間とした. 汇濫ピーク流量は流 入開始から約 30 分ごろで約 $5000 \mathrm{~m}^{3} / \mathrm{s}$ である. また, 汇濫 水の流入時間は約 1 時間 30 分であり, 総流入量は約 960 万 m゙゙ある.

\section{(2) 計算結果及び検討}

\section{(a) 氾濫特性}

図-4で示した解析結果と同じ流入条件で地上および地 下空間浸水において危険側の評価をするために道路のみ を汇濫水が流れるものとし, 下水ネットワーク, 地下空 間出入口を考慮したモデルで汇濫解析を行った. なお， ポンプ場からの排水に関しては高潮汇濫による流入が起 こっている際には河川の水位が上昇し排水が不可能なた め, 流入時間の1時間 30 分から30分後の 2 時間で潮位が下 がると想定し，解析開始から2時間はポンプの稼働を停 止している. 図-5に計算結果である高潮汇濫水の浸水深 の時間変化を示す. 流入のピークは約60分後である. 約

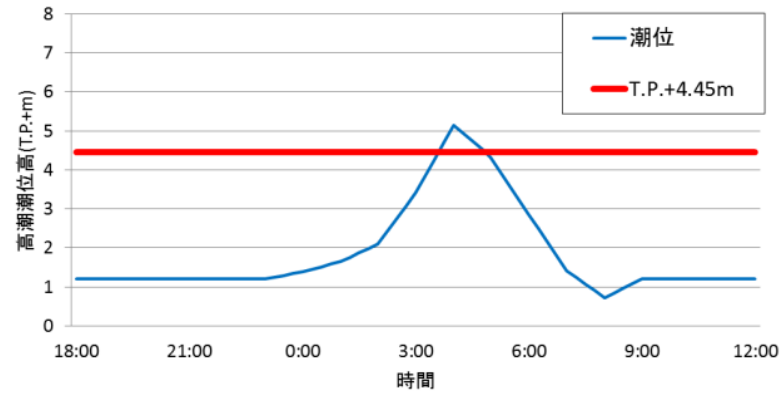

図-3 潮位変動

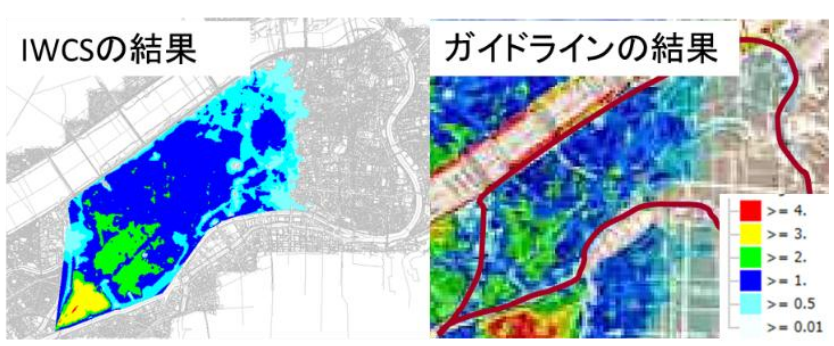

図-4 解析の検証結果

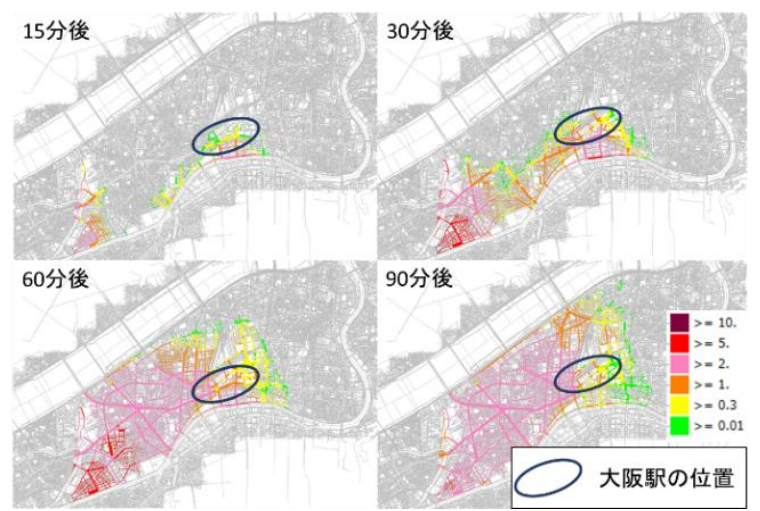

図-5 浸水深の時間変化

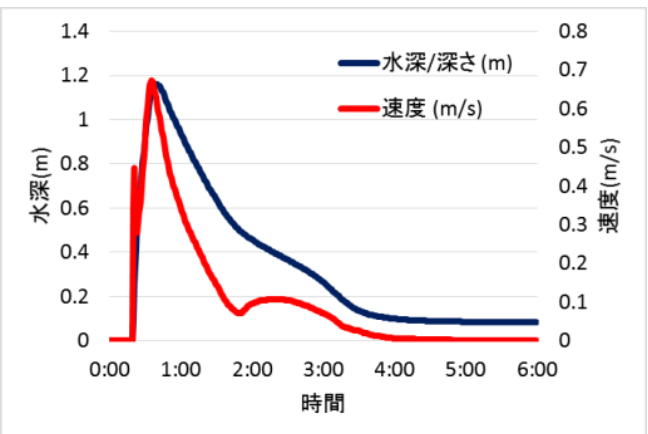

図-6 大阪駅周辺の水深と流速

100分後に浸水面積が最大となる.この時の浸水面積は 約219haであり，計算領域の道路の面積は323haであるの で約68\%が道路冠水したことになる．流入箇所が安治川 と堂島川のため, 汇濫流は対象地域の南西側から流入し, 約15分で中心地である大阪梅田まで到達する. 図-6に大 阪駅の南側の大通りの流速と浸水深の変化を示寸. 大阪 駅は図-5にある青く囲った部分に位置する．流入開始か ら約30分後には浸水深が1mを超える結果となった．ま た, 対象地域の西側においては最大浸水深が $2 \mathrm{~m}$ を超え るところがほとんどであった。これは対象地域の西側が 
海抜ゼロメートル地帯に存在することに起因する．梅田 周辺では $2 \mathrm{~m} を$ 超える浸水深は確認できないが，地下空 間の出入口を考慮しており，汇濫水が地下空間に流れ込 んだからである。また，流速は最大で $0.7 \mathrm{~m} / \mathrm{s}$ となり，同 時刻に浸水深もピークの $1.2 \mathrm{~m}$ となり, 逃げ遅れれば避 難困難になり，流されてしまう。

\section{(b) 雨水排水施設の効果}

図一ーにポンプ場の稼働状況を示す。対象地域には海老 江下水処理場, 北野抽水場, 出入橋抽水場, 天満堀川抽 水場があり，それぞれの排水能力は順に $60 \mathrm{~m}^{3} / \mathrm{s}, 28 \mathrm{~m}^{3} / \mathrm{s}$, $7 \mathrm{~m}^{3} / \mathrm{s}, 15 \mathrm{~m}^{3} / \mathrm{s}$ である. 天満堀川抽水場はポンプが最大ま で稼働していない．この抽水場は対象地域の東側の地盤 の高いところに位置しているためポンプの稼働が少なく なったものと考えられる. 終末処理場である海老江下水 処理場は約10時間後まで最大排水量で稼働している。モ デル内で完全に排水が終わるのは解析開始より約9時間 から10時間が経過した頃である．また，台風の影響によ りこれらのポンプ場が機能停止したケースの解析も行っ た. 流入条件は同じもので, ポンプによる排水機能が停 止した条件で行った. 図-8はポンプ場が稼働している結 果としていない結果の比較図である。 それぞれ6時間後 と9時間後のものである. ポンプ場の稼働が停止してし まった場合，ポンプ車などを使用しなければ長期浸水に よる被害が発生することが考えられる.

\section{(c) 地下空間流入特性}

図-9にモデル内に考慮している地下空間流入口を示寸. また，表-1に対象地域の地下駅一覧を示す。(1)は野田阪 神・海老江，(2)福島と新福島，(3)は玉川，(4)は中津， (5)は扇町，6)は中崎，(7)は天神橋筋六丁目，8は南森 町・天満である. (5) (8)は実質, 流入がなかったため省 略している. 大阪梅田周辺の大規模地下空間には高潮氾 濫により氾濫水が多く流入することが計算から明らかと なった. モデルで考慮している地下空間への入口は地下 街出入口と地下駐車場と地下駅の出入り口である. 地上 の浸水深が出入り口の高さを上回っている時間は流入が 続いているため大量の氾濫水が地下空間を襲う。大阪梅 田の地下空間は流入個所の近くに出入り口が存在するた め流入開始からすぐに浸水する結果となった．また，地 下駐車場も梅田の大規模地下空間と同様に梅田中心地に 位置しているため早い時間からの流入が確認される結果 となった. 梅田の大規模地下空間に接続している地下駅 以外の駅は福島, 新福島, 野田, 海老江, 中津, 中崎町, 天満，天神橋筋六丁目，玉川である．それぞれが対象地 域の様々な場所に位置しており, 駅ごとに危険度などが 違う。対象地域の西側に位置する福島, 新福島, 野田, 海老江，玉川はこの地域がゼロメートル地帯に位置する こともあり，多くの汇濫水が地下駅に流れ込んでいる. それに対して扇町や天神橋筋六丁目は地盤の高い東側に 位置しているため計算上，流入は全く見られない結果と なった.

\section{(d) 地下空間流入量}

図-10に梅田の大規模地下空間の出入口をエリア別に 示す. 表-2に梅田の大規模地下空間における出入り口数 と流入個所数と流入量を示す. 129 か所の出入り口の内 流入があったのは118か所である.11か所の流入がな かったところはいずれも地盤高の高い場所に位置してい たりマウンドアップにより流入が阻止されていたりした これは現地調査により確認済みである. 梅田の大規模地

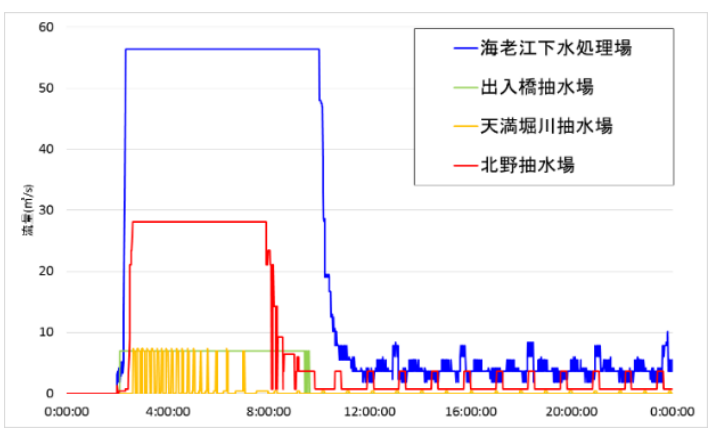

図-7 ポンプの稼働状況

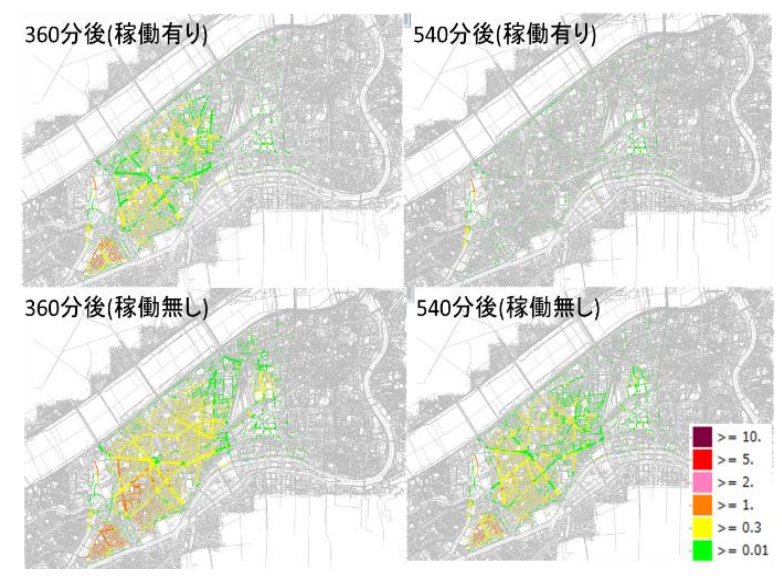

図-8ポンプの排水影響

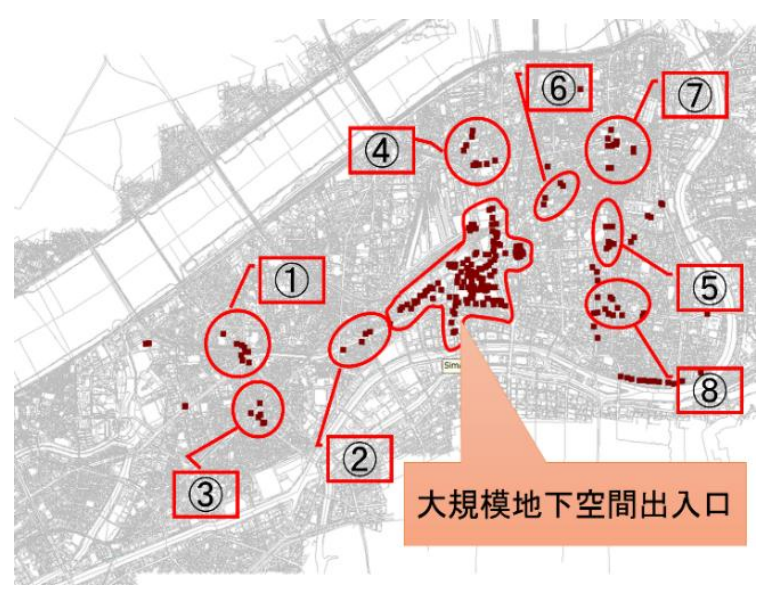

図-9 大規模地下空間と地下駅の位置

表-1 対象地域の地下駅

\begin{tabular}{|c|c|c|c|c|}
\hline & $(1)$ & $(2)$ & $(3$ & 4 \\
\hline 出入口数 & 9 & 5 & 6 & 10 \\
\hline 流入箇所数 & 9 & 5 & 6 & 10 \\
\hline 流入率 $(\%)$ & 100 & 100 & 100 & 100 \\
\hline 総流入量 $\left(\mathrm{m}^{3}\right)$ & 130 万 & 77 万 & 92 万 & 13 万 \\
\hline
\end{tabular}




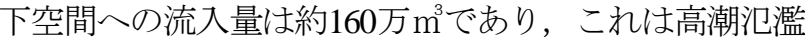
の総流入量の約 $17 \%$ にあたる．また，地下駐車場はモデ ル内に5か所考慮されており, 流入は5か所確認できた.

表-2に地下駅への流入量を示寸。ゼロメートル地帯に存 在し流入個所が近い福島, 新福島, 野田, 海老江, 玉川 は20万 $\mathrm{m}^{3}$ を越える流入が確認できた。 また，この地域の ほとんどの場所が $2 m$ を越える浸水深となるため高潮の発 生する規模の台風の接近が確認できたら地下空間の閉鎖 や避難を迅速に行わなければならない，中津や中崎町一 の流入量は他の地下駅に比べると少ない. この2駅と流 入個所との間に梅田の大規模地下空間が存在するため多 くがそちらに流れ込んだと考えられる．また，地下空間 全体への流入量は 475 万 $\mathrm{m}^{3}$ ある。.これは総流入量の約 50\%にあたる. 既往の研究より内水汇濫，津波氾濫によ る対象地域一の危険性が明らかとなっている. 内水汇濫 では総降雨量297万 $\mathrm{m}^{3} の 11 \%$ にたる32万 $\mathrm{m}^{3} か ゙ ，$ 津波汇 濫では総流入量 583 万 $\mathrm{m}^{3}$ の $70 \%$ あ゙あ 405 万 $\mathrm{m}^{3}$ が地下空間 一浸水している. 外力が異なると氾濫特性や浸水経路, 浸水時間や危険個所が変わってくる. 既往研究では, 内 水汇濫と津波氾濫の比較検討がされており, 本研究の比 較対象である内水氾濫と津波氾濫の解析結果は浅野らの 行った既往研究4)の結果を用いた. 高潮氾濫時と津波氾 濫時と内水汇濫時の大規模地下空間への累積流入量と時 間変化を図-11に示す．高潮汇濫において本研究での高 潮汇濫水が流入している時間は約1時間30分である. 高 潮汇濫時は，大規模地下空間への総流入量は約 160 万 $\mathrm{m}^{3}$, 流入開始から約6分で地下空間浸水が始まり45分にピー クを迎える．高潮は氾濫水の流入時間が1時間 30 分ある ため，地下空間へも時間をかけて流入する．それに対し， 津波汇濫では流入開始から約5分で大規模地下空間へ流 入し，約12分後にはピークを迎える. 津波汇濫において は短時間で大量の汇濫水が流れ込む．また，高潮氾濫の 流量のピークは約 $365 \mathrm{~m}^{3} / \mathrm{s}$ であり, 既往研究で設定した内 水汇濫の降雨条件を基準とすると約6倍となり，水害の 要因や規模によりピーク流量, 流入時間, 浸水時間が異 なることがうかがえる.

\section{3．高潮汇濫による大規模地下空間浸水}

\section{(1) 方法と条件}

本研究と既往の研究における地上部での汇濫解析の大 規模地下空間への流入量を外力とし，地下空間における 浸水解析を行った．地上部の解析における流入のあった 地下空間出入り口の流入量を地下浸水解析のモデルに流 入量として与えた. 計算モデルは, 森兼ら ${ }^{8}$ の汇濫計算 モデルを用いた．通路から店舗や改札を汇濫流が通過す るときの透過率をそれぞれ設定しており，ドア型の店舗 では透過率 0.5 , 開放型の店舗は 1.0 , 改札は 0.8 とた. フロアレベルの高低差は現地実測によるものでメッシュ

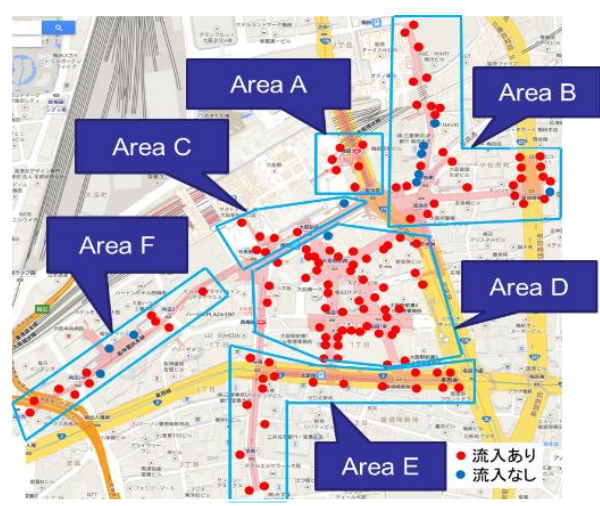

図-10 梅田の大規模地下空間出入口

表-2 大規模地下空間への流入量 (エリアごと)

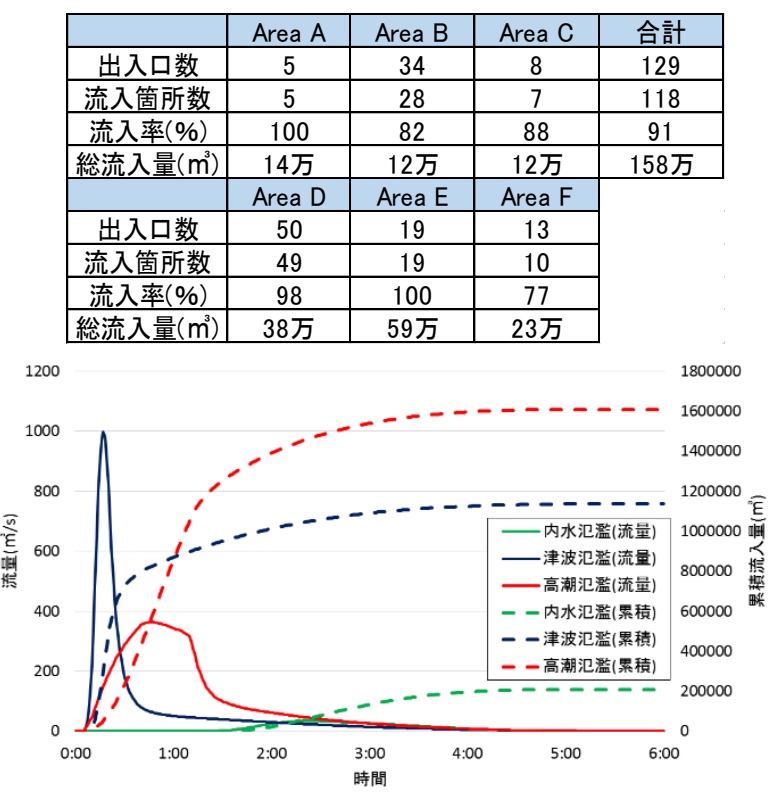

図-11 大規模地下空間への累積流入量と流量のグラフ

サイズは $2 \mathrm{~m} の$ 正方格子である. 粗度係数は 0.020 とし, 計算差分時間は0.005秒である．モデル内の地下駅につ いては地下駅の存在する場所の地盤高を低くし，氾濫水 が溜まるような設定を行っている．外力となる地上の氾 濫解析については本研究で行ったスーパー台風を考慮し た高潮汇濫解析と既往の研究での条件下での津波氾濫, 内水氾濫で行った.

\section{(2) 計算結果及び検討}

図-12に地下空間での浸水割合毎の氾濫水の拡がりを 示す．それぞれ浸水面積率10\%の時と50\%の時のもので ある. 外力によって流入場所，浸水が始まる個所が異な る. 高潮, 津波氾濫は安治川, 堂島川から流入している ので南西から浸水が始まり, 内水汇濫においては東側か ら流入が始まった．浸水率が10\%に達寸るまでの時間は 高潮汇濫で7分, 津波氾濫で10分, 内水汇濫で90分であ る. 浸水面積率が50\%に達するまでの時間は高潮汇濫で は14分, 津波氾濫では17分, 内水汇濫では117分であっ た．高潮氾濫と津波氾濫の浸水経路はほとんど同じであ るが，図-11にも示したようにピーク時間が違い波形も 


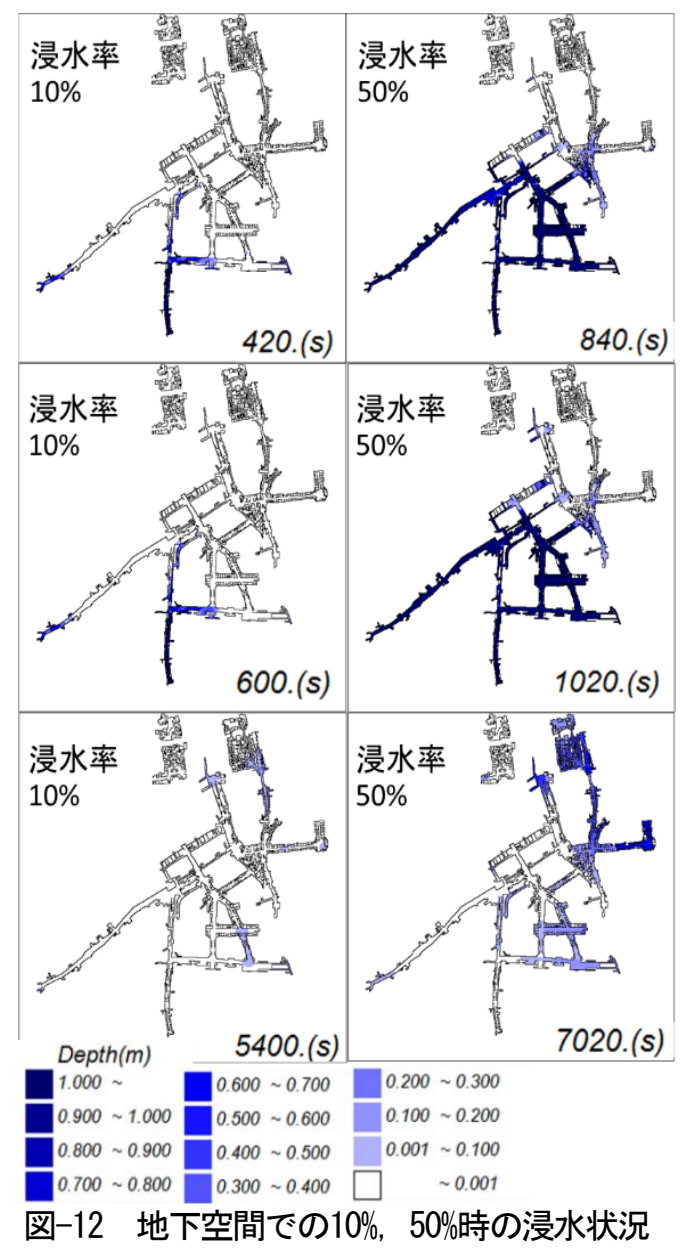

(上 : 高潮汇濫，中 : 津波汇濫，下: 内水汇濫)

異なるため，同じ浸水面積率でも津波氾濫の方の浸水深 が大きいことが明らかとなった．また，既往研究より内 水氾濫時，津波氾濫時には地下空間に流入した氾濫水が 地下駅に流れ込み60分後には水が引いているとされてお り，内水氾濫では地下空間流入量の約77\%が，津波氾濫 では $85 \%$ \%゙地下駅に流れた。 高潮汇濫では地下駅には流 入量の $78 \%$ である約 125 万 $\mathrm{m}^{3} の$ 汇濫水が流れ込む結果が 得られた. 高潮汇濫と津波汇濫は地下空間流入の特性が 似ているが，高潮汇濫では事前に止水板の設置や避難行 動を取ることが出来る.

\section{3. まとめ}

本研究ではスーパー台風による高潮が大阪市北区梅田 周辺に及ぼす被害予測計算を行った。高潮汇濫解析を行 い汇濫水の挙動について考察を行い, 対象地域内に存在 する下水処理場の稼働時，非稼働時の比較検討を行い長 期浸水についての考察を行った. また, 既往研究の比較 結果に本研究の結果も加えて地下空間への流入特性や浸 水状況などについて検討を行った.

流入開始から約 15 分には梅田の中心地一汇濫流が到達 し, 約30分後には市街地周辺の浸水深は1mを超える. ピーク後はゼロメートル地帯や地下空間に流れ込み地上
の浸水深は小さくなる. 浸水被害の長期化に関しては, ポンプの電源喪失や損傷があり十分に稼㗢できないケー スにおいて浸水から二日たっても $30 \mathrm{~cm}$ 以上の浸水深残 る結果となった.

大規模地下空間一の流入特性を高潮汇濫，津波汇濫， 内水汇濫で比較した結果, 高潮と津波では流入が始まっ て10分以内に地下空間への流入が確認された. それに対 して内水汇濫は降雨開始から1時間 30 分後に浸水開始す ることが知れた．汇濫水の広がり方も高潮・津波氾濫と 内水汇濫では異なり, 前者では大規模地下空間の南西側 から広がり，内水氾濫では東側から広がる結果となった。

大規模地下空間における水災害ごとの浸水対策や避難 について, 高潮汇濫は台風の接近により発生するため, 事前対策が行える. そのため, 止水板の設置や土囊の設 置が可能である. しかし，止水板を設置しても流入があ ることに変わりはないので避難が必要であり, 地下空間 での安全避難に関する検討を行い，防災・減災対策を検 討していく予定である.

謝辞 : 本研究を遂行するにあたり，データを提供してい ただいた関係各位に心から謝意を表します。

\section{参考文献}

1) IPCC: Climate Change 2013: The Physical Science Basis, pp. 7, 2014.

2）森兼政行 - 石坦泰輔 - 尾崎平 - 戸田圭一: 大規模地下空間 を有する都市域における地下空間への内水汇濫水の流入特 性とその対策，水工学論文集，Vol. 55，2011.

3）尾㠃平，石垣泰輔，戸田圭一：高密度商業地域における内 水汇濫の脆弱要因に関する考察, 土木学会論文集 B1 (水 工学), Vo168, N0. 4, I_1009-I_1014, 2012.

4）浅野統弘・尾崎平・石垣泰輔・戸田圭一: 南海卜ラフ巨大 地震による津波襲来時の大規模地下空間の浸水予測, 土木 学会論文集 B1 (水工学), Vol.70, No.4, I_1435-I_1440, 2014.

5）大阪湾高潮対策協議会 : 大阪湾高潮対策危機管理行動計画 ガイドライン, 2010.

6) 関根正人・池田遼: 東京東部低平地を対象とした浸水・氾 濫の数值予測, 土木学会論文集B1 (水工学), Vol. 70, No. 4, I_1429-I_1434， 2014.

7）武田 誠・小寺大輔・松尾直規: 格子内の地盤高特性を考 慮した簡便な汇濫解析法に関する研究, 水工学論文集, 第 52 巻, 853-858, 2008.

8）森兼政行, 井上知美, 石坦泰輔, 尾㠃平, 戸田圭一: 地下 駅を考慮した大規模地下空間での浸水特性と浸水対応策の 効果に関する検討，土木学会論文集 B1 (水工学)，Vol68， No. 4, I_1003-I_1008, 2012.

9）大阪地下街株式会社：梅田地下空間避難確保計画, http://whity. osakachikagai. jp/files/user/pdf/escape_ plan. pdf, 2012.

(2014. 9. 30受付) 